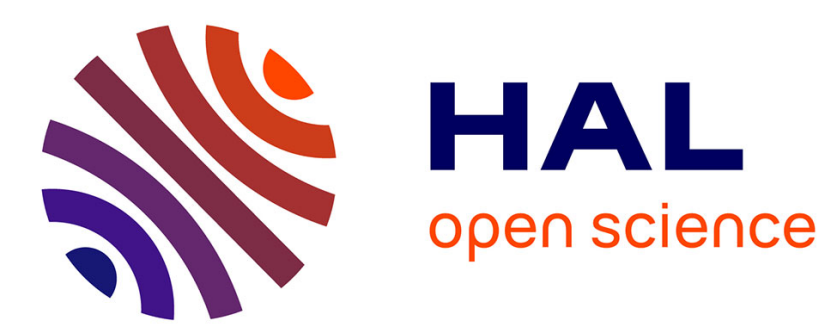

\title{
Destinies of artistic activity: visual artists' plural forms of employment and trade-offs in a French region
}

Isabelle Mayaud, Laurent Jeanpierre

\section{To cite this version:}

Isabelle Mayaud, Laurent Jeanpierre. Destinies of artistic activity: visual artists' plural forms of employment and trade-offs in a French region. Sociologia del Lavoro, 2020, 157, pp.125-144. hal03043071

\section{HAL Id: hal-03043071 \\ https://hal.science/hal-03043071}

Submitted on 19 Dec 2021

HAL is a multi-disciplinary open access archive for the deposit and dissemination of scientific research documents, whether they are published or not. The documents may come from teaching and research institutions in France or abroad, or from public or private research centers.
L'archive ouverte pluridisciplinaire HAL, est destinée au dépôt et à la diffusion de documents scientifiques de niveau recherche, publiés ou non, émanant des établissements d'enseignement et de recherche français ou étrangers, des laboratoires publics ou privés. 
Citation : Isabelle Mayaud, Laurent Jeanpierre, "Destinies of artistic activity: visual artists' plural forms of employment and trade-offs in a French region", in Pierre Bataille, Sonia Bertolini, Clementina Casula, Marc Perrenoud (coord.) "From atypical to paradigmatic? Artistic work in contemporary capitalist societies", Sociologia del lavoro, $2020, \mathrm{n}^{\circ} 157$, p. $125-144$

DOI: $10.3280 /$ SL2020-157007

Nous contacter : laurent.jeanpierre@univ-paris1.fr ; isabelmayaud@gmail.com

Résumé : Reposant sur une enquête récente qui porte sur le travail artistique dans une région française, l'article considère les artistes visuels comme une population témoin illustrant les destinées possibles du travail indépendant faiblement ou mal rémunéré dans le capitalisme contemporain. Les activités artistiques attirent principalement les diplômés et les personnes issues des classes supérieures qui acceptent néanmoins d'être très peu payé pour leur art et même, comme le feraient les entrepreneurs, d'investir régulièrement afin de poursuivre leur activité. Le maintien de leur vocation artistique nécessite alors le recours à des revenus secondaires provenant de prestations sociales, de ressources familiales ou le développement d'activités rémunératrices complémentaires. Toutes ces combinaisons possibles n'étant pas également accessibles, elles déterminent des régimes variables de production artistique, de présentations de soi et des articulations diverses entre activités salariées et non salariées, le cas limite étant l'abandon de la création.

\begin{abstract}
Based on a recent survey on the artistic work in a French region, the article considers visual artists as a control population illustrating the possible destinies of low or poorly paid self-employment in contemporary capitalism. Artistic activities mainly attract graduates and people from the upper classes who nevertheless accept to be paid very little for their art and even, as entrepreneurs would do, to invest regularly in order to continue their activity. The maintenance of their artistic vocation then requires recourse to secondary income from social benefits, family resources or the development of complementary remunerative activities. Since all these possible combinations are not equally accessible, they determine variable regimes of artistic production, self-presentation and various articulations between salaried and nonsalaried activities, the borderline case of which is the abandonment of creation.
\end{abstract}

\title{
Destini dell'attività artistica: le molteplici forme di impiego e i compromessi degli artisti visivi in una regione francese
}

Riassunto : Sulla base di una recente indagine sul lavoro artistico in una regione francese, l'articolo considera gli artisti visivi come una popolazione di controllo che illustra le sorti possibili del lavoro autonomo poco o mal retribuito nel capitalismo contemporaneo. Le attività artistiche attraggono soprattutto laureati e persone provenienti dalle classi superiori, che accettano di essere retribuite poco per la loro arte e persino, come farebbero gli imprenditori, di investire regolarmente per continuare la loro attività. Il mantenimento della loro vocazione artistica richiede il ricorso a redditi secondari provenienti da prestazioni sociali, risorse familiari o lo sviluppo di attività remunerative complementari. Poiché tutte queste possibili combinazioni non sono ugualmente accessibili, esse determinano regimi variabili di produzione artistica, di autopresentazione e varie articolazioni tra attività retribuite e non retribuite, il cui caso limite è l'abbandono della creazione. 


\title{
Destinies of artistic activity: visual artists' plural forms of employment and trade-offs in a French region*
}

\author{
Isabelle Mayaud $^{* *}$, Laurent Jeanpierre ${ }^{* * *}$
}

\section{Introduction}

Long ignored because of their marginal and atypical nature, artistic employment and work have been the subject of increased interest in sociology for the past twenty-five years. Some studies make this particular type of activity an empirical analyzer of the transformations affecting the capitalist mode of production (Chiapello, 1998; Boltanski and Chiapello, 1999; Menger, 2002; Borja and Sofio, 2009; Ducret and al. 2017). It is within this general framework that some research has highlighted the possible emergence of a "creative class" (Florida, 2002) (which would include, alongside artists, craftsmen, researchers, information and communication professionals and other symbol workers), or a class of "immaterial workers" (Moulier Boutang, 2008) who would be the first to be exploited in a new productive system, called "cognitive capitalism" by some authors (Moulier Boutang, 2008). The figure of the artist constitutes, for some researchers as well as for some activists, an inspiring figure of emancipation from the constraints of salaried work, whereas for others it represents, on the contrary, a repellent, exacerbating the new forms of exploitation and the precariousness of contemporary capitalism (Banks and Hesmondhalgh, 2009; Tasset, Amossé and Grégoire, 2013; Murgia, Maestripieri and Armano, 2016; Murgia, Maestripieri and Armano, 2017; Perrenoud and Bois, 2017). This figure of the artist at work also inspires sociological analyses of other activities, such as those related to digital platforms (Srnicek, 2017; Abdelnour and Méda, 2019), which also seem to question salaried employment. The atypical jobs of new forms of capitalism and artistic work would be emblematic of the advent of a new era of selfemployment or independent labour, around which absolutely opposite assessments are projected.

In France, salaried work still largely dominates the world of work. In fact, self-employment remains statistically a minority today throughout Europe ${ }^{1}$. Visual artists constitute an even more marginal population of workers. Moreover, the self-employed status of the vast majority of them is a long-standing constant, always observed over the most recent period and from one survey to the next ${ }^{2}$. Artistic work and artists are therefore not ahead of the transformations that have affected the labour market since the 1980s because, in most countries, they have almost always escaped the norm of the modern wage system (Ducret and al., 2017, p. 239). In this sense, this

\footnotetext{
${ }^{*}$ Article submitted: 25/11/2019. Article accepted: 12/05/2020.

** Centre de recherches sociologiques et politiques de Paris. Email: isabelmayaud@gmail.com.

***Université Paris 8 - Saint-Denis. Email: laurentjeanpierre0@gmail.com.

1. According to OECD figures, the rate of self-employment remains a minority in the countries of the world for which this information is available in 2018: $22.9 \%$ of employment in Italy, $15.1 \%$ in the United Kingdom, $11.7 \%$ in France, $9.9 \%$ in Germany, and only $6.3 \%$ in the United States. https://data.oecd.org/fr/emp/taux-d-emploi-non-salarie.htm [Last Access October 2019].

2. The share of self-employed artists is around $80 \%$ among visual artists in France in 2011 (Gouyon, 2015b). In addition, in 2016, more than $70 \%$ of the working population (artists and non-artists) in the visual arts sector were self-employed (Turner, 2019).
} 
population is not in a position to directly provide information on a possible erosion of the wage society (Castel, 2009) or on a possible recomposition of the wage condition (Darbus, 2008). In this sector of activity, the problem of a possible deterioration in employment conditions as a result of a gradual shift from the wage system to a more entrepreneurial system, where the share of self-employment would increase, is obviously not the most relevant.

While artists are probably not the pioneers of a new employment regime, their sociological study could nevertheless contribute to the reflection on the transformations of socio-economic regulation in contemporary capitalist societies. Based on empirical data collected on the scale of a French region, this article intends to consider visual artists not as a pioneer population, but rather as a control population of the rise of self-employment in contemporary societies. In France, the share of self-employment is, in general, higher in the cultural sector than in other economic sectors ${ }^{3}$. And among the cultural sectors, the visual arts are certainly the most important area of self-employment. Because self-employment is historically and massively the norm in their sector, visual artists are therefore an appropriate population to question the effects of a flexible market and labour deregulation - a major socio-economic transformation of contemporary societies (Castel, 2009). In the context of a rise, supported by neo-liberal governments, in the standards of entrepreneurship and self-employment, the study of the case of visual artists provides a kind of indirect assessment of a labour market model that is often today a new ideological paradigm. In other words, the way artists deal with their artistic activity is of interest to us here in that it allows us to test from experience a regime of employment regulation that has already developed and would like to impose itself. In the field of visual arts, the time has come to take stock. In this sector, the French case is particularly interesting. A renewal of public action in favour of artists is currently taking place. The extent of inequalities between artists in the visual arts sector is indeed well known, even if the determination of the origin of these inequalities is still the subject of debate (Jeanpierre, 2012; Menger, 2012). These inequalities have become a political issue for at least two reasons. First, the population of artists in general has been growing steadily since the 1980s (Menger, 1991), which has contributed to the increase in the population of poor artists. The issue of poor artists, while not new, seems more massive and visible today (Pasero, 2013). Secondly, inter-sectoral comparisons are recurrent in France between visual artists and writers on the one hand and performing artists on the other. The latter, who work under the so-called intermittent regime (Grégoire, 2013), embody a model of risk socialisation of employment that is more successful than that of visual artists.

The survey conducted in the Grand Est region partly confirms the elements known at the national level, or in other French regions, on the socio-economic and professional living conditions of contemporary visual artists (Liot, 2004; FRAAP, 2008; AMAC, 2013; Ministère de la Culture, 2017; AMAC, 2018). "In the name of the love of art"4, visual artists live in conditions that can be described mainly as precarious and which can be explained by the atypical nature of this labour market (1). However, this general precariousness of artistic activity is differentiated by variable combinations that correspond to different ways of articulating artistic self-employment with other types of activities and income (2). This article aims at giving some of the clues that are necessary in order to analyze these combinations.

3. At the beginning of 2013 , non-salaried jobs represent $28 \%$ of cultural jobs, more than twice as much as that of the entire population (Bisault and Picard, 2017).

4. We borrow this formula from Maud Simonet who develops the case of the free work done by women "in the name of love" (Simonet, 2018). 


\section{Engaging in an atypical activity}

In order to describe the different ways of exercising the profession of artist today in the visual arts in France, we will base ourselves on the study of a French region: the Grand Est region (1.1). Analysed closely at the socio-economic and territorialized level of this administrative region, the conditions of contemporary visual artists's lives have the same general and paradoxical characteristics as those already recognized by the sociology of artistic employment. Artistic activity is paradoxical in nature because it attracts individuals with the same social characteristics as those belonging to the most valued socio-professional groups in society (1.2.) while, however, it brings in little or no money (1.3.) and even requires multiple and costly investments (1.4.), particularly personal investments (1.5.).

\subsection{Methodology}

Our analyses are based on the study of a population of artists residing and/or working permanently or temporarily in a French region which, at the time of the survey, had 5,552,388 inhabitants, or $8.4 \%$ of the national population ${ }^{5}$. Our observations were gathered as part of a survey commissioned in July 2017 by the regional directorate of the Ministry of Culture - the Direction régionale des affaires culturelles du Grand Est - and by the three territorial contemporary art networks in the region (Versant Est, LoRA, Bulles). This survey was carried out within the framework of a scheme promoted by the Ministry of Culture and aimed at a new territorial organisation of the Republic in a budgetary logic that saves public funds after a recent territorial reform that increased the number of French regions from 22 to $13^{6}$. The Grand Est region is the result of the merger of three former administrative regions: Alsace, Lorraine and Champagne-Ardenne. It now comprises ten French departments (Ardennes, Aube, Bas-Rhin, Haute-Marne, Haut-Rhin, Marne, Meurthe-et-Moselle, Meuse, Moselle and Vosges). At the time of writing this article, investigative work using multiple survey tools has been carried out or is in progress in several other regions of France: Bretagne, Hauts-de-France, Île-de-France, Nouvelle-Aquitaine, Pays de la Loire, etc. Our investigation in the Grand Est region comes at a time when public initiatives in favour of a better knowledge of the population of visual artists are multiplying and are supported or encouraged by the Ministry of Culture for operational purposes. The challenge, at different territorial levels, is to succeed in establishing the broad outlines of a specific policy of socio-economic and professional support for visual artists.

The analysis of the observations collected through the administration of two online questionnaires during the year 2018 constitutes the main research material. The choice of a questionnaire survey was made in order to give voice to the greatest number of professionals in the visual arts sector working throughout the territory and to address on a large scale the greatest number of questions concerning the supply and demand for artistic activity. A first questionnaire, accessible between February 20 and May 7, 2018, consisting of 106 questions, most of them closed, was designed for visual artists residing and/or working permanently or temporarily in the Grand Est region. A second questionnaire, accessible between August 2 and September 30, 2018, was designed for structures related to visual artists in the Grand Est region

5. Figures indicated on the region's website. Text available at the website http://www.grandest.fr/presentation accessed [Last Access October 2017].

6. Official documentation. Text available at the website http://www.gouvernement.fr/action/la-reforme-territoriale [Last Access October 2017]. See also: L'administration territoriale de l'État en mouvement, press kit, Council of Ministers, 31 July 2015. Text available at the website http://www.gouvernement.fr/sites/default/files/document/document/2015/07/dossier_de_presse_-_31_juillet_2015.pdf [Last Access October 2017]. 
and consisted of 102 questions. More than 1,500 artists and 189 structures were directly solicited. 669 usable questionnaires were collected for artists and 71 for structures. This is a significant total number of respondents for this scale of analysis ${ }^{7}$. In contrast to national surveys, the advantage of a territorialized and regional approach to artistic activity is to increase the chances of reaching the most precarious or least legitimate fractions of the artist population. Contrary to what has been done in most other recent surveys with the same type of population, our population was thus not predefined before data collection, whether on a fiscal, social or administrative basis. All individuals who define themselves as artists were brought to respond. As is the case at the national level, the proportion of self-employed workers in our population is overwhelming: only $2 \%$ of artists in the sample report working as salaried workers for the sole exercise of their activity as an artist (which does not exclude - and this is often the case that they may be employed elsewhere). In this article, we focus only on questions that reveal the economic and material conditions of the activity as they are returned or perceived by the artists themselves.

\subsection{A socially attractive profession}

Like many professionals in so-called vocational professions, many of the artists in our sample report an early desire to become an artist (38\% go back to childhood, $38 \%$ to adolescence, only $24 \%$ later). Only $21 \%$ of the artists declare that their artistic activity constitutes a "vocation" in the strict sense of the word. For them, it is first and foremost a "commitment" (28\%) and sometimes even a "work" (27\%). In the region we are dealing with, as elsewhere, there are a plurality of routes to become an artist. Social origins, gender, place and year of birth, i.e. generational affiliation, are the most apparent variables that make certain types of trajectories more likely than others. But these different components also provide a measure of the degree of attractiveness of the activity.

From the point of view of social origins, artistic employment appears to be a rather attractive market. Artists come from relatively privileged families. While there is certainly a preeminence of unemployed mothers, employed or in intermediate professions on the one hand, fathers are often executives, company managers or in intermediate professions on the other. The share of artistic parents (3\% among mothers and fathers) is relatively low. If the contemporary artists can therefore be considered as being mainly "inheritors", it is above all from an economic point of view rather than in terms of specifically artistic resources that would have been transmitted by their parents.

More generally, the probabilities of being an artist in the region studied vary according to 1) whether you were born to a worker (16\% of the sample), farmer $(3 \%)$ or manager $(36 \%)$ father, 2 ) whether you were born male $(47 \%)$ or female $(53 \%), 3)$ whether you were born in the Grand Est region $(53 \%), 4)$ wheter your age group: $27 \%$ of the artists in the sample are between the ages of 25 and 35, and $9 \%$ are over the age of 66 . These characteristics are all features that make it possible to assess the degree of attractiveness of the artist's profession. This represents a desirable - and of course a feasable - activity for people with economically inherited social positions that are higher than average. However, judging by income levels, the situation is quite different.

\footnotetext{
7. The response rate is rather important here compared to the level of participation recorded in other surveys. Within the framework of a national survey initiated by the Federation of networks and associations of visual artists (a major player in the sector in France) in 2008, 1243 questionnaires were collected (FRAAP, 2008).
} 


\subsection{Work that does not pay}

All sociological surveys dealing with the visual arts sector show that this artistic activity is not very remunerative economically. The low economic rewards resulting from this are even more dramatic when correlated to the average level of skills (Ministère de la Culture, 2017).

While revenues from cultural occupations are generally lower than those of other sectors (Gouyon, 2015a), they are particularly low for visual artists. In the population we studied, 84\% of people report income attributable solely to artistic activity of $€ 12,000$ or less per year. And $66 \%$ of them actually earn only small incomes from this activity, less than or equal to 6,000 euros per year. In addition, it is an eloquent fact that $11 \%$ of artists received no income from their artistic activity in 2017 (see Graph. 1) . $^{8}$.

Graph. 1. Income distribution (for the last year)

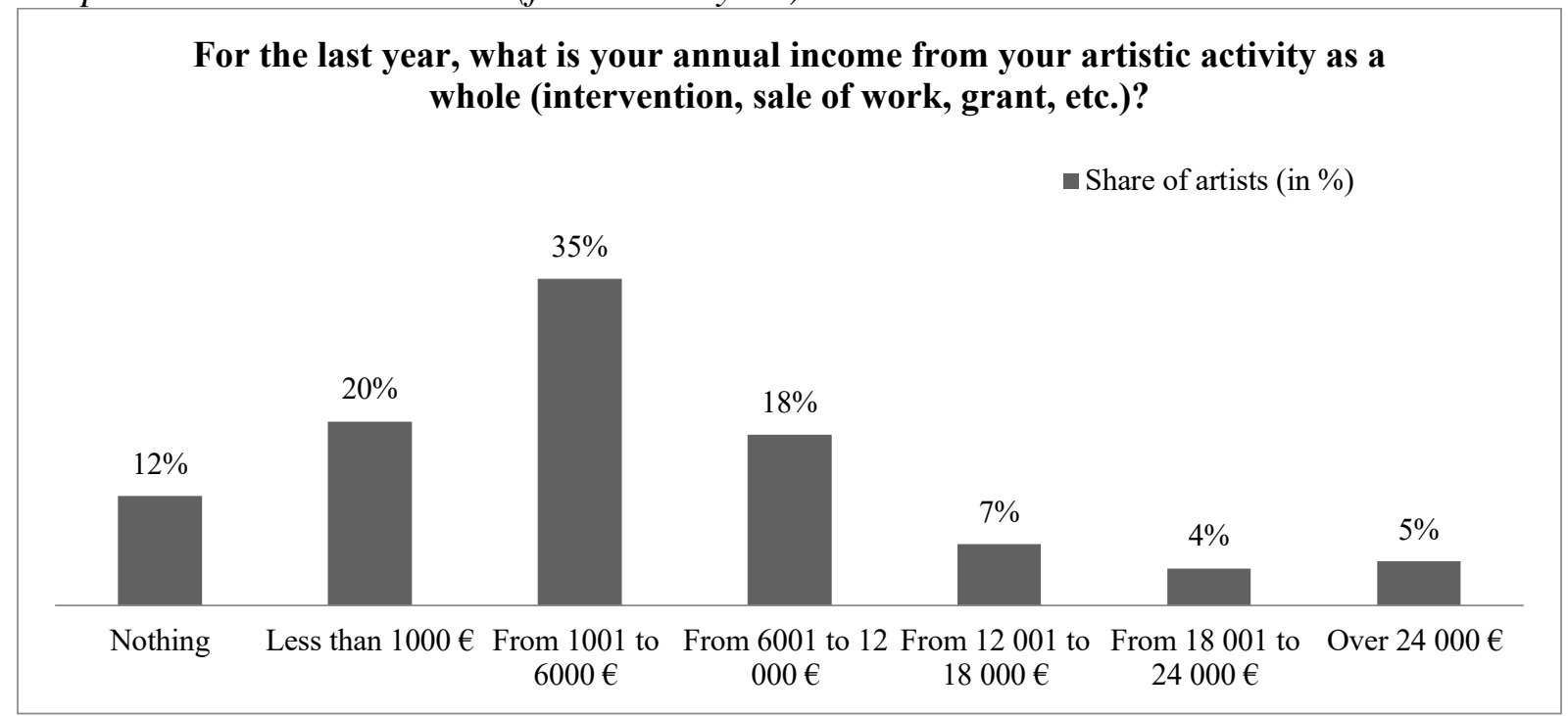

The breakdown of income distribution shows that sales of works $(41 \%)$ and copyright income (19\%) are the main sources of artistic income today. Other sources of income allowances and scholarships, conference attendance, exhibition fees, etc. - appear to be minor.

As the main share of specifically artistic income, sales of works provide low revenues, both in frequency and amount: $82 \%$ of artists have sold a work in the last three years and almost two thirds of them in the last twelve months. Only $5 \%$ of artists never sell their works. Direct sales, without intermediaries, are important: this is the most frequent case for $54 \%$ of artists, and an occasional practice for $30 \%$ of them. Most sales are therefore not made through gallery owners which is an indication of the low level of recognition of the artist in our sample. Historically, the art market has indeed developed concomitantly with the figure of the dealer-gallery owner (White and White 1965; Giuffre, 1999; Jeanpierre, Mayaud and Sofio, 2012). In fact, only 24\% of the artists in the sample say that they are represented by one or more galleries. The majority of the artists in the sample do not benefit from the recognition of intermediaries, who historically hold a crucial position in the visual arts market, which is an indication of their low level of recognition that goes hand in hand with low remuneration. Moreover, the works fall into four main price ranges: $9 \%$ of artists charge very low prices (less than 100 euros), $48 \%$ of them fix prices between 101 and 1000 euros, 34\% of them between 1001 and 3000 and only

8. It should be noted that the proportion of women who do not declare any income or less than 1000 euros for the year is high. 
$9 \%$ reach a segment that can be described as high range (more than 3001 euros). While $1 \%$ of artists report selling works in a price range above $€ 10,001$, most derive very little income from them. Other incomes are necessary and they usually come from other activities (cf. 2.1).

\subsection{Artistic work at any cost}

To fully and properly assess the economic attractiveness of artistic activity, it is also necessary to take into account the expenses that condition this activity. The survey shows here the importance, often overshadowed, of direct economic investment by artists themselves to produce and exhibit their works.

A first investment item is linked to the establishment of a production space. In most cases, place of residence and place of work are confused. While $1 \%$ of the artists report being homeless at the time of this survey, most of them live in apartments $(41 \%)$ or detached houses $(34 \%)$. Almost two thirds (64\%) have a home with a surface area between 31 and $110 \mathrm{~m} 2$. Only $10 \%$ have a housing workshop. The share of homeowners (33\%) and first-time homeowners (10\%) is relatively high but below the national average ${ }^{9}$. The share of tenants is dominant and higher than that observed in other social groups (49\% compared to $39.6 \%$ in France in $2013^{10}$ ). $6 \%$ of artists report that they do not have a dedicated workplace. It can be hypothesized that these are artists who work in public spaces, such as cafés, with computer as their main working tool. For most artists, working at home is the norm which is an indicator of a high and shared level of precariousness. Almost half (46\%) of artists report working from home, either in a common space $(15 \%)$ or a dedicated space $(31 \%) .9 \%$ have an accommodation workshop. $39 \%$ of them work outside their homes. The cost of these production spaces may seem relatively moderate: $24 \%$ spend less than 50 euros per month on their dedicated premises, $53 \%$ between 51 and 300 euros, and only $7 \%$ spend more than 501 euros on them. But if we compare these figures with average incomes, the place of production is a significant area of expenditure.

The cost of the workplace is often added to other costs that determine the performance of artistic work, in particular direct investment in production. Thus, $60 \%$ of them declare that they have systematically self-financed the production of their works, and $29 \%$ frequently over the last three years. For the majority of artists (64\%), the amounts invested monthly are between 51 and 300 euros (see Graph. 2).

\section{Graph.2. Direct investment in artistic production}

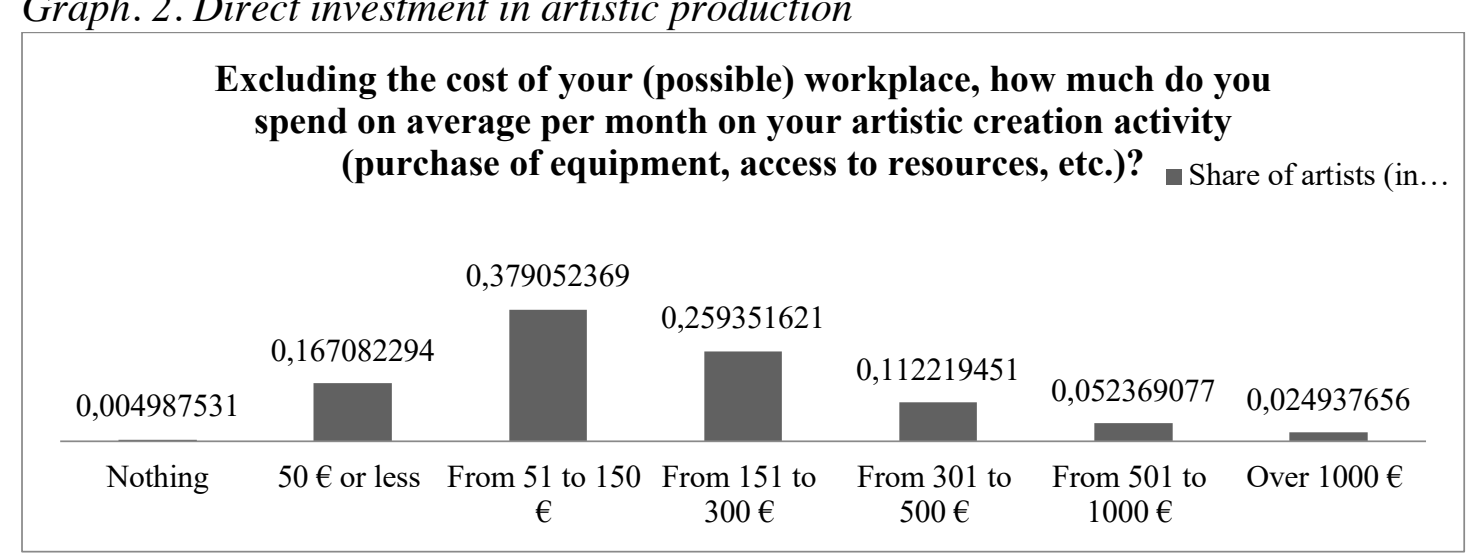

9. According to the latest figures from INSEE, the share of owners is $58 \%$ in France in 2018 . Text available at the website https://www.insee.fr/fr/statistiques/3676698?sommaire=3696937 [Last Access February 2020].

10. https://www.insee.fr/fr/statistiques/3676698? sommaire=3696937 [Last Access February 2020]. 
Among the artists' other areas of investment, there is also the cost of exhibiting and distributing works. Almost half of the artists report that they have already paid with their own money to present their works in an exhibition $(47 \%)^{11}$. The amounts are sometimes very large: between 2,000 and 6,500 euros, with a median value of around 150 euros. These may be socalled participating fees, membership fees, etc.

While they may seem relatively modest when analysed one by one, all these capital expenditures are nevertheless constrained and recurring and weigh on the artistic activity income of artists, who are themselves mostly under 500 euros per month. In the name of "the love of art", the possibility of working for free, or even at a loss, is therefore not absent from the ordinary exercise of the visual artists' activity.

\subsection{Personal investments}

However, engaging in the artist's life also involves a significant investment of time that is not artistic per se.

More than one in three artists in our survey devote between twenty and forty hours per week to all tasks related to artistic activities that are not creative tasks (design, manufacturing, administration, communication, fundraising, etc.) while $44 \%$ of them declare that they manage to devote more than 20 hours a week to sheer creative activity (research, production). However, the proportion of time specifically devoted to research and creation remains relatively too low for many: less than two hours per week for $4 \%$, and between two and ten hours for $23 \%$ of artists (see graph. 3).

\section{Graph.3. Share of weekly time dedicated to research and creation}

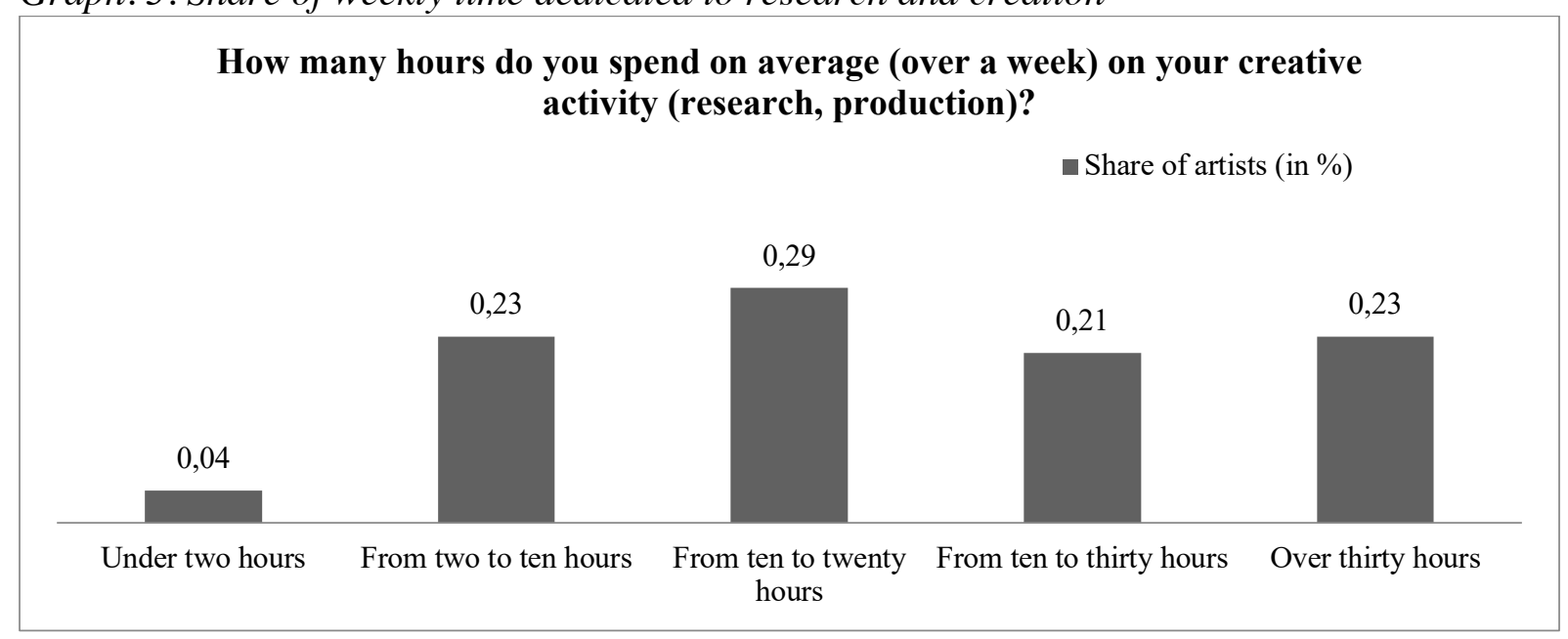

As has already been observed for other self-employed workers, self-employment is not conducive to a good balance between family and working life (Landour, 2019a; Landour, $2019 b$ ). For instance, there is a higher rate of the visual artists of our study without children than in other occupations at the national level: half of them report having no children at all. One in three of these artists has two or more children. For women, the rate of respondents without children is particularly high: $57 \%$ of the female visual artists in our sample have no children,

11. Not taken into account here are the commissions retained by the galleries in the context of their activity of representing artists nor the contribution of the artists in constructing the exhibition spaces. 
while $42 \%$ of men have no children. In addition, $27 \%$ of women have two or more children, compared to $41 \%$ of men.

The exercise of the artist's activity in the region we have studied may seem paradoxical insofar as it attracts a socially well-endowed population even though the net incomes and living conditions it promises seem unattractive. In other words, for the majority of artists, engaging in the artist's life is nowadays synonymous with financial downgrading, unless low income from artistic activity is compensated for by other sources of income. This apparent paradox is not new and has been often observed in the sociology of artistic professions (Becker, 1982; Menger, 1999). It also and more broadly concerns many of the new self-employed workers whose level of qualifications does not have the protective effect, which would spare them the experience of socio-economic precariousness ${ }^{12}$. To the extent that income from artistic activity remains low, most of these self-employed people are forced to find other solutions to maintain their artistic activity. This commitment to the life of the artist induces in this sense trade-offs which, although they remain specific to each individual, nevertheless present certain regularities.

\section{Finding the right balance to remain artist and self-employed}

If artists do not necessarily live from their art, they can live more or less well with artistic self-employment. In other words, there are more or less happy combinations, more or less comfortable ways, economically and subjectively, of being and remaining self-employed in the arts. For most artists, it consists in dealing with other sources of income and with one or more other activities. In this sense an artist is more than an artist: he has other activities by which he can try to remain an artist (2.1.). While this logic of combining activities is now the standard of professional life for visual artists, it varies from one group of individuals to another and does not have the same impact (2.2.). In the long run, it can sometimes even compromise the very exercise of the artist's activity (2.3.).

\subsection{More than an artist and more than an independent worker}

Given the low net income generated specifically by the artistic activity itself, the combination of activities and sources of income is the norm for visual artists. This is reflected in the fact that income from artistic activity represents the total income for just over a quarter of the artists who responded to our survey. Conversely, for almost half (45\%) of them, artistic income represents less than a quarter of the total income of the last past year. Few artists are in fact full-time artists (Menger, 1989; Perrenoud, 2007; Bureau, Perrenoud and Shapiro, 2009) especially in countries where, as in the French case, artistic supply and demand remain centralized: business opportunities tend to be less important in the periphery, which in this case means outside Paris ${ }^{13}$.

In the region we studied, $42 \%$ of artists report that they carry out one or more other paid professional activities outside artistic creation activities on their own account. Education is the main other sector of employment for more than a third (35\%) of them, in higher arts schools,

12. Precariousness refers to uncertain employment and living conditions that do not allow people to project themselves into the future. Many empirical studies analyze this relationship to work (Tasset, Amossé and Grégoire, 2013; Tasset, 2015; ContariniHak and Marsi, 2015 ; see in particular Jeanpierre and Mayaud, 2015).

13. On the centrality of Paris, see the seminal article of Menger (1993). All recent studies confirm this concentration of resources in the Île-de-France region to the detriment of the other French regions (Calvier and al., 2018). 
public secondary schools or high schools, and at university. The cultural sector, widely understood (cinema, circus, dance, literature, music, theatre, etc.), is the second most important sector of employment for $20 \%$ of them, with a slight predominance of the visual arts over other fields of activity. However, the income from these side income-generating activities remains average or low. A quarter of the artists receive with them, less than 600 euros per month (see Graph. 4).

\section{Graph. 4. Income from another professional activity}

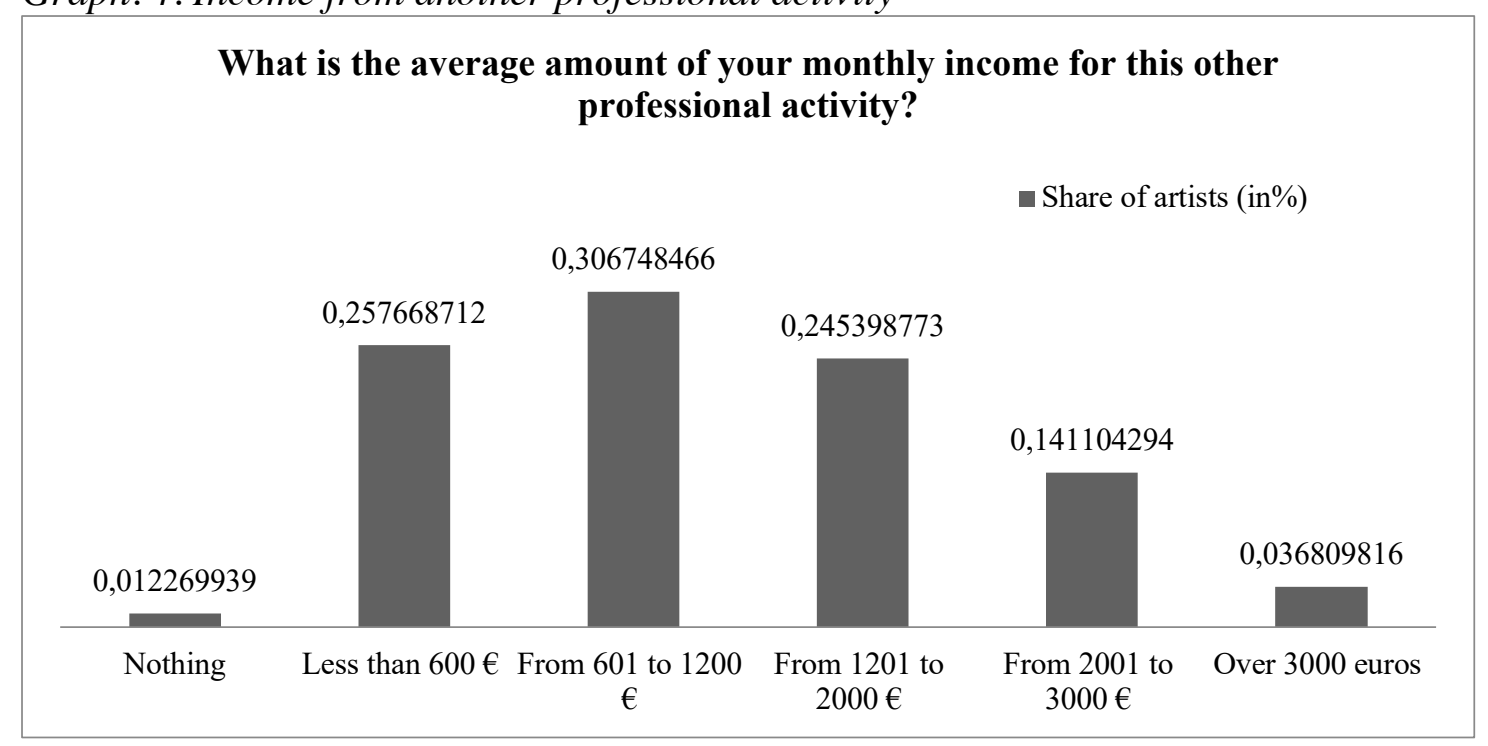

For some, an additional income is therefore ensured by a second complementary activity or even by several other activities. For others, the necessary additional income comes from existing social redistribution mechanisms in France, such as the Revenu de solidarité active $\left(\mathrm{RSA}^{14}\right)$ for the poorest populations (14\% of respondents receive it) or unemployment benefits $(10 \%)$. In other cases, the low income accumulated by the artist is partly offset by the economic support of the spouse (15\%), the financial support of the parents $(8 \%)$ and the occupation of free housing owned by parents or relatives.

In any case, the multiplication of income-generating activities and sources of income appears to be the cardinal norm of the status of visual artists in contemporary France. In this sense, visual artists share the condition of many artists from other sectors: forced to "self-multiply" (Menger, 1997), the contemporary artist is a fundamentally "plural artist" (Bureau, Perrenoud and Shapiro, 2009). Non-artistic activity or activities, although not very remunerative, occupy an imposing place in weekly working time: between ten and twenty hours for $24 \%$ of them, between twenty and thirty hours for $25 \%$, and more than thirty hours for $29 \%$ of people.

\subsection{Combinations and variations of income and activities}

However, this multiplication of activities has variable modalities. Carrying on an artistic activity without any other source of income is first and foremost to accept an uncertain relationship towards the future. In terms of earnings, $68 \%$ of visual artists with no other source of income report their retirement as unlikely or very uncertain, while $56 \%$ of those with other

\footnotetext{
14. The amount of the RSA for a single person is 559.74 euros. Its obtention is conditional on the place of stable residence
} (France) and age (25 years or more). https://www.service-public.fr/particuliers/vosdroits/F19778 [Last Access October 2020]. 
sources of income consider it in the same way. In contrast, the fact of exercising another professional activity does not make it possible to compensate for the uncertainties induced by the activity of self-employed artist: those who do not have another professional activity consider their retirement unlikely or very uncertain at 59\% and those who exercise another professional activity are $63 \%$ to have this feeling. In other words, retirement seems more secure for those who have additional sources of income but not for those who have an activity complementary to their artistic practice. This apparent paradox is probably due to the low income from these other professional activities (see above). But it also makes it possible to formulate the hypothesis that the activity of self-employed artist provides less uncertainty about the future if one benefits from family economic support (parental, conjugal, etc.).

This hypothesis seems all the more solid given that an overwhelming majority of the artists surveyed $(85 \%)$ believe that the exercise of another professional activity has been a significant obstacle to the development of their artistic career. It should be noted that this accumulation of activities seems even more penalizing in the case of women. Of all those who carry out another activity, $85 \%$ declare that they have encountered obstacles. The proportion of women among those $85 \%$ who report encountering barriers is higher (62\%) than that of men (38\%). Many women who have no other sources of income have only one child (20\% of them, compared to $15 \%$ of men in the same situation) while men who have other sources of income are more likely to have two or more children than women in the same situation (35\% compared to $30 \%$ ).

While for men and women, accommodating low artistic income and possible pluriactivity does not mean the same thing (Buscatto, 2007; Cacouault-Bitaud, Ravet, 2008; Ravet, 2013; Miller, 2016), on the other hand, social origin (understood through the socio-professional category of the father's affiliation) does not seem to be decisive in defining the various existing relationships to the economic precariousness of artistic life. The age variable is more significant, particularly for the youngest and oldest artists. Between the ages of 25 to 35 and over 66, artists more often have other sources of income without having to engage in any other professional activity.

The combinations between sources of income and complementary activities are therefore multiple, depending in particular on the sex or age of the artists. For some of them, we can speak of a double life, as Bernard Lahire understands it (Lahire, 2006). They are based on a fragile balance that may compromise for some the activity of the artist itself even if this other income-generating activity, which is not an artistic activity, is not necessarily negatively assessed as an obstacle to independence. Nearly one in three artists believe that it contributes to their balance, even though nearly half of the artists consider it to be "food", and a little more than a third consider it to be too time-consuming.

\subsection{Representing and declaring oneself as an artist}

If the population of visual artists has for so long posed problems of definition for sociologists, this is due in particular to the coexistence of several ways of declaring their professional situation to public administrations. In the French case, there are indeed several tax and social security regimes of reference each governing artistic activity in a non-univocal or exclusive manner. The complexity of this recording system is such that, for many visual artists, the legal aspects of the exercise of their activity remain unclear (AMAC, 2013). Self-declaring oneself as an artist today in France is thus not obvious from a legal point of view. But this objective difficulty also reflects more subjective feelings expressed by the artists themselves. 
The plurality of artists' activity and remuneration regimes derives not only from the variable place of the creator's or artist's independent activity in them, but they also command diversified modes of presentation and self-definition.

It explains why, when asked about their professional activity, visual artists often respond by accumulating names or in a vague and uncertain way («I do different things», answers for example a 30-year-old respondent, born in Paris) ${ }^{15}$. Similarly, self-declaring of one's activity remains problematic for writers (Heinich, 1995). These responses also reveal several regularities: the combination of distinct activities (symbolized by the and in self-definitions of oneself); their non-substitutability, or the fact that they are highlighted according to the context; the importance of the technique, the medium, the doing, to be able to define oneself beyond the multiplication of the self. The artist is not only plural because he practices a plurality of activities, s/he is also plural because s/he represents and presents him- or herself to others in a variable or multiple way. This multi-faceted identity representation is likely to contribute to fuelling a double precariousness, not only objective, but also subjective ${ }^{16}$.

The subjective self-representations that visual artists have of themselves, on the one hand, and, on the other hand, the value they place on the combinations of income and activities that result from the choice of artistic independence as a life horizon are therefore both variable. These representations also reflect compromises and constant efforts to be and remain an artist not only for others but also for oneself.

\section{Conclusion}

In order to question contemporary attitudes towards self-employment, this article presented some elements of a recent survey conducted by questionnaire on the artistic work of visual artists in a French region. The results confirm that artistic activities mainly attract graduates and people from privileged social backgrounds who nevertheless accept to be paid very little for their art and even, as entrepreneurs would do, to invest regularly in order to continue their activity. Studies conducted in other regions indicate that this condition is shared by artists elsewhere in France, and an ongoing national survey seems to confirm these observations ${ }^{17}$. The objective precariousness of artistic activity is often combined with a subjective feeling of precariousness of professional identity, which makes this population doubly vulnerable. In the case of French visual artists, the socialization of these risks experienced individually is not collective but relies primarily on personal and family arrangements. As we conclude this article, the question of living conditions of visual artists in France is the topic of various discussions. It follows the submission of the so-called Racine report, named after Bruno Racine, senior adviser at the Cour des Comptes, a French administration in charge of controlling the regularity of public accounts ${ }^{18}$. Beyond the question of the strong inequalities of income between artists, this report observes a problem of wealth sharing between the different protagonists of the art

\footnotetext{
15. The first question in our survey was open and read: «When you are asked what is your professional activity, what do you answer? »

16. On the gaps between an objectively precarious reality and a reality subjectively perceived as precarious, see Duvoux and Papuchon (2018).

17. AMAC, 2013; AMAC, 2018. The result of a national study conducted by Frédérique Patureau and Jérémy Sinigaglia should be published in the course of year 2020 .

18. Presented on Wednesday 22 January 2020 to the Minister of Culture Frank Riester, this report intitled The Author and the Creative Act aims at contributing to the adaptation of public policies in favour of artist-authors.
} 
world. The Ministry's intervention here attests to the failure of the model of a market that is self-regulating and naturally redistributing wealth.

The low economic remuneration of artists for their artistic labour requires the ability to combine different sources of income or to build up a portfolio of remunerative activities. These combinations of income and activities in order to exercise an artistic activity and to remain a professional artist as long as possible often lead to compromises which have an impact on family life, but also on professional life and career. However, depending on age and gender among other factors artists are not equal in the art of articulating and cumulating these different resources. The higher than national average rate of privileged social backgrounds artists may also explain both financial risk taken and the ability to combine different activities. Our survey indicates the extent to which the combinations are more or less favourable to the continuation and perpetuation of the artist's activity, and probably also to full self-realisation, the borderline case of which is the abandonment of creation.

Beyond its particularities, the concrete sociological study of the artistic activity of visual artists thus illustrates some possible destinies of the development of low or poorly paid selfemployment in contemporary capitalism. But it also shows how forms of employment, wageearning and non-salaried employment in particular, cannot always be opposed but are, for some agents, on the contrary conjugated diachronically but also synchronously. Far from a sudden shift from wage-earning to non-salaried employment, neoliberal capitalism is therefore now rather having the effect of confronting a growing part of the population with various forms of employment, throughout life on the one hand, and in the same time-period of activity on the other (Chicchi, Savioli, Turrini, 2014). For the sociologist, the empirical and theoretical challenge is then to relate the varying modalities of this combination of independence and wageearning (or other sources of income) to the social properties of individuals. And to evaluate the effects of these new forms of employment on work engagement.

\section{References}

Abdelnour S., Méda D. (2019). Les nouveaux travailleurs des applis. Paris : PUF.

AMAC (2013). Observation participative et partagée des arts visuels en Pays de la Loire. Étude socioéconomique des acteurs des Pays de la Loire : structures, artistes, professions intermédiaires. Text available at the website http://amac-web.com/content/6conseil/opp_arts_visuels_2013.pdf [Last Access April 2020].

AMAC (2018). Parcours de l'artiste : premiers éléments. SODAVI Ile-de-France. Text available at the website http://tram-idf.fr/pdf/TRAM_Livret_SODAVI_WEB.pdf [Last Access April 2020].

Banks M., Hesmondhalgh D. (2009). Looking for work in creative industries policy. International Journal of Cultural Policy, 15, 4: 415-430. DOI: 10.1080/10286630902923323.

Becker H.S. (1982). Art worlds. Berkeley: University of California Press.

Bisault L., Picard T. (2017). La culture, une activité capitale, Insee Première, n 1644.

Boltanski L., Chiapello È. (1999). Le nouvel esprit du capitalisme. Paris : Gallimard.

Borja S., Sofio S. (2009). Productions artistiques et logiques économiques : quand l'art entre en régime entrepreneurial. Regards Sociologiques, 37-38 : 23-43.

Bureau M.-C., Perrenoud M., Shapiro R. (eds). (2009). L'artiste pluriel : démultiplier l'activité pour vivre de son art. Villeneuve-d'Ascq : Septentrion. 
Buscatto M. (2007). Femmes du jazz. Musicalités, féminités, marginalisations. Paris : CNRS Editions.

Cacouault-Bitaud M., Ravet H. (2008). Les femmes, les arts et la culture. Frontières artistiques, frontières de genre. Travail, genre et sociétés, 1, $\mathrm{n}^{\circ} 19: 19-22$. DOI : 10.3917/tgs.019.0019.

Calvier C., Casarotti A., Camors C., Soulard O. (2018). L'Île-de-France, première région française de l'économie culturelle. Insee Analyses. ${ }^{\circ} 82$.

Castel R. (2009). La montée des incertitudes : travail, protections, statut de l'individu. Paris: Éditions du Seuil.

Chiapello È. (1998). Artistes versus managers : le management culturel face à la critique artistique. Paris : Éd. Métailié.

Chicchi F., Savioli M., Turrini M. (2014). Soggettività intermittenti. Un'inchiesta sulla scomposizione del lavoro nell'ambito delle industrie creative, Sociologia del Lavoro, 133: 42 - 57. DOI: 10.3280/SL2014-133003.

Contarini-Hak S., Marsi L. (ed). (2015). Precariato: forme e critica della condizione precaria. Verona: Ombre corte.

Darbus F. (2008). L'accompagnement à la création d'entreprise. Actes de la recherche en sciences sociales, 175 : 18-33. DOI: 10.3917/arss.175.00018.

Ducret A. et al. (2017), Introduction: Artistic Work as a "Laboratory" of Labour Market Deregulation? Swiss Journal of Sociology, 43, n 2: 239-52. DOI: 10.1515/sjs-2017-0014.

Duvoux N., Papuchon A. (2018). Qui se sent pauvre en France? Revue francaise de sociologie, Vol. 59, 4: 607-647. DOI: 10.3917/rfs.594.0607.

Florida R. L. (2002). The rise of the creative class: and how it's transforming work, leisure, community and everyday life. New York: Basic Books.

FRAAP. (2008). Les artistes plasticiens et la formation professionnelle. Cahiers 3 de la FRAAP. Text available at the website https://fraap.org/IMG/pdf/cahier_3_lect.pdf [Last Access April 2020].

Gouyon M. (2015a). Revenus d'activité et niveaux de vie des professionnels de la culture. Paris: Ministère de la Culture, Département des études, de la prospective et des statistiques.

Gouyon M. (2015b). Dossier. Les non-salariés dans les activités culturelles. In INSEE, Emploi et revenus des indépendants, Insee Références, 59-73.

Grégoire M. (2013). Les intermittents du spectacle: enjeux d'un siècle de luttes (de 1919 à nos jours). Paris: La Dispute.

Giuffre K. (1999). Sandpiles of Opportunity: Success in the Art World. Social Forces 77, $\mathrm{n}^{\circ} 3$ : 815-32. DOI: $10.2307 / 3005962$.

Heinich N. (1995). Façons d'“être écrivain". L'identité professionnelle en régime de singularité. Revue française de sociologie, XXXVI: 499-524. DOI: 10.2307/3322166

Jeanpierre L. (2012). De l'origine des inégalités dans les arts. Revue française de sociologie, 53, $\mathrm{n}^{\circ} 1: 95-115$. DOI : 10.3917/rfs .531.0095.

Jeanpierre L., Mayaud I. (2015). Un precariato frammentato. Il commissario d'esposizione d'arte contemporanea in Francia. In Contarini-Hak S. e Marsi L. (ed.), Precariato: forme e critica della condizione precaria, Verona: Ombre corte, 80-91.

Jeanpierre L., Mayaud I., Sofio S. (2012). Sociohistoire des intermédiaires du marché de l'art (XVIIIe-XXIe s.). (Rapport de synthèse pour le programme ANR IMPACT).

Lahire B., Bois G. (avec la collab.) (2006). La condition littéraire: la double vie des écrivains. Paris: La Découverte.

Landour J. (2019a). Sociologie des Mompreneurs : entreprendre pour concilier travail et famille? Villeneuve-d'Ascq : Presses universitaires du Septentrion.

Landour J. (2019b). L'indépendance favorise-t-elle l'articulation travail / famille? Connaissance de l'emploi. Text available at the website 
http://ceet.cnam.fr/publications/connaissance-de-l-emploi/l-independance-favorise-t-elle-larticulation-travail-famille--1076672.kjsp [Last Access April 2020].

Liot F. (2004). Le Métier d'artiste. Paris: L'Harmattan.

Menger P.-M. (1989). Rationalité et incertitude de la vie d'artiste. L'Année sociologique: 111151.

Menger P.-M. (1991). Marché du travail artistique et socialisation du risque: le cas des arts du spectacle. Revue française de sociologie, 32 , $\mathrm{n}^{\circ}$ 1: 61-74. DOI: 10.2307/3322356.

Menger P.-M. (1993). L'hégémonie parisienne. Économie et politique de la gravitation artistique. Annales, 48, 6: 1565-1600. DOI: 10.3406/ahess.1993.279232

Menger P.-M. (1997). La profession de comédien: formations, activités et carrières dans la démultiplication de soi. Paris: Ministère de la culture et de la communication, Département des études et de la prospective.

Menger P.-M. (1999). Artistic Labor Markets and Careers. Annual Review of Sociology, 25: 541-574. DOI: 10.1146/annurev.soc.25.1.541.

Menger P.-M. (2002). Portrait de l'artiste en travailleur : métamorphoses du capitalisme. Paris: Seuil.

Menger P.-M. (2012). Réponse à Laurent Jeanpierre. Revue francaise de sociologie, vol. 53, $\mathrm{n}^{\circ}$ 1: 117-26. DOI: $10.3917 / \mathrm{rfs} .53130117$.

Miller D. L. (2016). Gender and the Artist Archetype: Understanding Gender Inequality in Artistic Careers. Sociology Compass, 10 : 119-131. DOI: 10.1111/soc4.12350.

Ministère de la Culture (2017). Rapport du Gouvernement au Parlement sur la situation des arts visuels. Paris: Ministère de la Culture.

Moulier Boutang Y. (2008). Le capitalisme cognitif: la nouvelle grande transformation. Paris: Éditions Amsterdam [1st ed. 2007].

Murgia A., Maestripieri L., Armano E. (2016). The precariousness of knowledge workers: hybridisation, self-employment and subjectification. Work Organisation, Labour \& Globalisation, 10, 2, 1-8. DOI:10.13169/workorgalaboglob.10.2.0001.

Murgia A., Maestripieri L., Armano E. (2017). The precariousness of knowledge workers (Part 2): forms and critiques of autonomy and self-representation. Work Organisation, Labour \& Globalisation, 11, 1: 1-9. DOI: 10.13169/workorgalaboglob.11.1.0001.

Pasero U. (2013). Why Artist Go Unpaid. In Van den Berg K., Pasero U., Art Production beyond the Art Market? Berlin : Sternberg Press.

Perrenoud M. (2007). Les musicos. Enquêtes sur des musiciens ordinaires. Paris: La Découverte.

Perrenoud M., Bois G. (2017). Artistes ordinaires: du paradoxe au paradigme? Variations autour d'un concept et de ses prolongements. Biens symboliques/Symbolic Goods [en ligne], 1, Text available at the website https://www.biens-symboliques.net/88 [Last Access April 2020].

Ravet H. (2013). 38. Genre et travail artistique. In Maruani M. Travail et genre dans le monde. L'état des savoirs. Paris: La Découverte, 399-408.

Simonet M. (2018). Travail gratuit : la nouvelle exploitation? Paris: Textuel.

Srnicek N. (2017). Platform capitalism. Cambridge, Malden: Polity.

Tasset C. (2015). Les intellectuels précaires, genèses et réalités d'une figure critique. Doctorat de sociologie, Luc Boltanski (dir). Paris : EHESS.

Tasset C., Amossé T., Grégoire M. (2013). Libres ou prolétarisés ? Les travailleurs intellectuels précaires en Île-de-France. Text available at the website https://halshs .archives-ouvertes.fr/halshs-00966696/document [Last Access April 2020].

Turner L. (2019). Le poids économique direct de la culture en 2017. Paris: Ministère de la Culture, Département des études, de la prospective et des statistiques. 
White H. C. and White C. (1965). Canvases and careers: institutional change in the French painting world. New York: Wiley. 